\title{
Medicinal plant exudativory by the Bengal slow loris Nycticebus bengalensis
}

\author{
Nabajit Das ${ }^{1,2,3, *}$, K. A. I. Nekaris ${ }^{3}$, P. C. Bhattacharjee ${ }^{1,2}$ \\ ${ }^{1}$ Department of Zoology, Gauhati University, Guwahati-14, Assam, India \\ ${ }^{2}$ Primate Research Centre NE India, Guwahati-12, Assam, India \\ ${ }^{3}$ Nocturnal Primate Research Group, Oxford Brookes University, Oxford OX3 0BP, UK
}

\begin{abstract}
Slow lorises are members of a rare guild of obligate exudativores. Secondary metabolites in their diet have been implicated as contributing to the evolution of both their slow basal metabolism and their venom. No long-term study has yet examined the feeding ecology of the largest of the lorises, the Bengal slow loris Nycticebus bengalensis. We conducted an 18 mo study from June 2008 to December 2010 in Hollongapar Gibbon Wildlife Sanctuary, Assam, India, to investigate whether Bengal slow lorises prefer gum, and whether there is any evidence of secondary metabolites in their diet. We detected the lorises along line transects using existing trails and followed each animal as long as possible, recording selected behaviours via focal instantaneous sampling. We recorded 629 feeding incidents during 270 night walks. We found that up to $80.9 \%$ of feeding bouts were of plant exudates, followed by bark, floral parts, insects, fruits, and tender (i.e. immature) leaves. Within the plant exudate category, 5 species were consumed in $71 \%$ of the total exudate feeding bouts: Terminalia chebula, Mesua ferrea, T. arjuna, Ficus hispida and Dillenia indica. These species all have high medicinal value and are commonly used by the local communities for traditional medicinal purposes. Absorption of secondary metabolites from these plants may explain unusual healing patterns observed in wild slow lorises, but lacking in lorises held in captivity. Their dietary affinity towards medicinal plants could explain patterns of use of slow lorises within the traditional medicine trade in the Indo-Chinese region.
\end{abstract}

KEY WORDS: Lorisidae $\cdot$ Exudativory $\cdot$ Feeding ecology $\cdot$ Secondary metabolite $\cdot$ India Resale or republication not permitted without written consent of the publisher

\section{INTRODUCTION}

Feeding ecology is a central component of a species' biology and helps researchers to understand many aspects of its anatomy (Lehman et al. 2005), survival, reproduction, group dynamics (Garber 1987), habitat requirements and social structure (Eisenberg et al. 1972). Dietary research highlights the impacts of environmental factors that most affect animal ecology (Poulsen et al. 2001) and explains the constraints which limit their distribution. The exploitation of rare or difficult-to-digest resources by some primates may aid in their ability to avoid competition with other animals in their environment (Ganzhorn 2002), and may also lead to evolutionary advantages regarding health and anti-predator defence systems (Forbey et al. 2009).

One such adaptation by a handful of primate genera is the ability to excavate and consume plant exudates. Nash \& Burrows (2010) and Smith (2010) reviewed the dietary, behavioural and morphological correlates of exudativory in primates. Exudativory is an important but relatively rare feeding adaptation for more than 70 species of primates including strepsirrhines (cheirogeleids, galagids and lorisids), callitrichids, and some Old World monkeys (cercopithecids). Exudates are a family of foods including gums and saps that offer a carbohydrate-rich energy source, yet one which at the same time may contain difficult- 
to-digest secondary metabolites (Heymann \& Smith 1999). Only 6 primate genera (Calithrix, Mico, Cebuella, Phaner, Euoticus and Nycticebus) are known to access these foods through active excavation of plant surfaces (Starr \& Nekaris 2013). These obligate exudativores include exudates in $\geq 40 \%$ of their feeding time (hereafter referred to as diet; Nash \& Burrows 2010).

Until the mid-1990s, virtually nothing was known about the feeding ecology of wild slow lorises (Nycticebus spp.), and the discovery that these small primates consumed large quantities (comprising nearly 40 to $90 \%$ of the diet) of exudates was surprising; indeed it had been predicted that like the similarly non-leaping pottos of Africa, loris diet would comprise mainly fruits (Ravosa 1998). Several morphological characters of these nocturnal strepsirrhines suggest the presence of obligate exudativory, including a stout toothcomb, small body size, a large caecum, a long tongue, wide U-shaped legs and enlarged hand pads for gripping (Hladik 1978, Nekaris et al. 2010). Wiens et al. (2006), Swapna et al. (2009) and Starr \& Nekaris (2013) all provided strong evidence that exudates are a preferred food for slow lorises (selected disproportionately often relative to their abundance within the habitat) rather than a fallback food (food used when preferred items are not available; Marshall \& Wrangham 2007).

The Vulnerable Bengal slow loris Nycticebus bengalensis is the largest (1100 to $2100 \mathrm{~g}$ ) of the 8 slow loris species and is distributed across Southeast Asia (northeastern India, Myanmar, Bhutan, Bangladesh, Laos, Cambodia, Vietnam, Thailand and China). Three short-term wild studies have provided evidence for exudativory within this widely dispersed species in different habitat types (dry acacia scrub forest, Swapna et al. 2010; lowland rainforest mixed with plantations, Pliosungnoen et al. 2010; and montane rainforest mixed with grassland, Rogers \& Nekaris 2011). In a 5 mo study of unmarked individuals, Swapna et al. (2009) revealed that although they also consumed nectar, plant bark, fruits and small invertebrates, the majority of their wild diet comprised plant exudates (86.5\% of all feeding events).

Here we report on the diet of Nycticebus bengalensis based on an 18 mo eco-behavioural study of freeranging Bengal slow lorises in a wet semi-evergreen forest in India; this is the first long-term (over more than 1 yr) study of this species. We examined the prevalence of loris exudativory across multiple seasons. Using selectivity, we examined whether exudates are a preferred or fallback food for lorises in our study area. We also conducted a qualitative examination to investigate secondary metabolites in the chosen food items, and discuss the evolutionary implications of these dietary choices.

\section{MATERIALS AND METHODS}

\section{Study area}

We conducted the eco-behavioural study on Bengal slow lorises from June 2008 to December 2010 in Hollongapar Gibbon Wildlife Sanctuary (HGWLS), in Assam, India. HGWLS (Fig. 1) is situated at $26^{\circ} 40^{\prime}$ to $26^{\circ} 45^{\prime} \mathrm{N}$ and $94^{\circ} 20^{\prime}$ to $94^{\circ} 25^{\prime} \mathrm{E}$, at an altitude of 100 to $120 \mathrm{~m}$, and has an area of $20.98 \mathrm{~km}^{2}$. It is located on the south side of the Brahmaputra River in the district of Jorhat, Assam. The vegetation type in HGWLS is Assam plains alluvial semi evergreen forests, sparsely interspersed with wet evergreen forest patches (Champion \& Seth 1968). The vegetation is composed of several canopy layers; most of the components are evergreen in character (Champion \& Seth 1968). The top canopy is predominated by Dipterocarpus macrocarpus and Artocarpus chama;

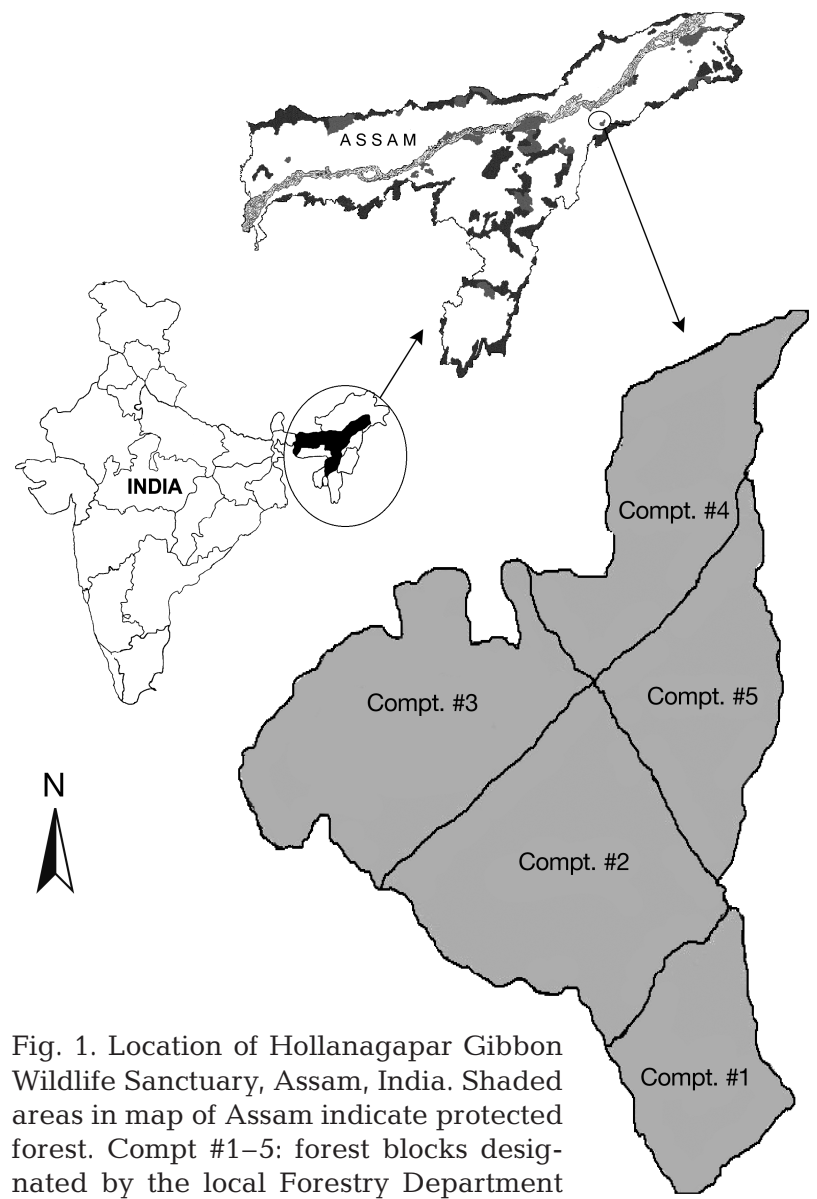


Mesua ferrea is the dominant species in the middle canopy, whereas the lower and ground layers consist of a variety of evergreen shrubs and herbs, the most common being Teinosstachyum dullooa and Pseudostachyum polymorphum. HGWLS is an isolated forest fragment, and the ecology and the behaviour of a species, including the Bengal slow loris, may be influenced by fragment-mediated changes.

Based on differences in minimum daytime temperature, the study site can be classified into 2 distinct weather periods, i.e. subtropical hot wet summer (May to August) and cool dry winter (September to April).The average temperature varies from $5^{\circ} \mathrm{C}$ (minimum) to $38^{\circ} \mathrm{C}$ (maximum), and average rainfall recorded is around $249 \mathrm{~cm}$.

\section{Field methods}

At night, transect walks were conducted on preexisting trails using red-filtered headlamps (Petzl Zoom 4.5 V with xenon halogen bulbs, MYO-3). After locating an individual, we followed it as long as possible, resulting in 216 follows ranging from 10 to $260 \mathrm{~min}$; except for 2 cases, all follows were of single individuals. We combined continuous focal animal sampling (during feeding; Altmann 1974) and instantaneous point sampling at 5 min intervals (for general activity) (cf. Nekaris 2001, Nekaris \& Rasmussen 2003). All observations of feeding behaviours were recorded ad libitum (Altmann 1974).

Feeding bouts were timed using a digital wristwatch. We scored a feeding bout when an individual procured and/or handled food items with hands or mouth, as well as when it chewed and ingested food. Foraging (i.e. the search for food) was not considered as part of the feeding bout. Each independent feeding bout was separated by 5 consecutive minutes during which the individual was engaged in an activity other than feeding or if the individual switched to feeding on a different food type. Length of a feeding bout is defined as continuous feeding or handling for more than 10 s (Powzyk \& Mowry 2003) and was considered over when feeding ceased. When the animal was feeding, we recorded (1) duration of the feeding bout, (2) canopy level, (3) position in the tree, (4) substrate inclination, (5) plant species eaten, (6) plant parts eaten and (7) a description of the feeding tree (height, crown diameter, canopy cover and diameter at breast height, DBH, ca. $1.3 \mathrm{~m}$ above ground level). We distinguished 6 food categories: plant exudates, plant bark, floral parts/nectar, fruits, immature leaves and invertebrates.

\section{Vegetation sampling}

To study the abundance of tree species, we used the strip transect sampling method (Struhsaker 1975, Williamson 1993), creating straight lines through the forest along predetermined compass bearings. We laid out 12 fixed transects $(500 \times 4 \mathrm{~m})$ within the areas where we frequently encountered slow lorises; all transects were at least $500 \mathrm{~m}$ apart. Once these transects were established, trees with $\mathrm{DBH}>10 \mathrm{~cm}$ were sampled.

Methods described here followed the ethical principles of the international guidelines for the study of nonhuman primates concerning the use of animals and conformed to the ethical norms of all institutions involved in this study and the current laws of India.

\section{Data analysis}

Percentage of feeding time was calculated as the percentage of time the animal devoted to different food types in each season derived from the continuous focal animal sampling data. Time spent feeding on each of these plant parts indicates feeding preferences and was used to generate a ranked order of preference for food items. For comparison with earlier studies (Swapna et al. 2009), to estimate relative preference for or avoidance of plant species in the diet, we used 'Vanderploeg and Scavia's relativized electivity index' $\left(E_{i}^{*}\right)$ (Lechowicz 1982) for exudates only:

$$
E_{i}^{*}=\left[W_{i}-(1 / \mathrm{n})\right] /\left[W_{i}+(1 / \mathrm{n})\right]
$$

where $W_{i}=E_{i}{ }^{\prime} / \Sigma E_{i}{ }^{\prime}$ and $E_{i}{ }^{\prime}=r_{i} / p_{i}$ and $r_{i}$ is the percentage of time spent feeding on plant species $i_{1} p_{i}$ is the percentage availability of species $i$, and $\mathrm{n}$ is the total number of species in diet. $E_{i}^{*}$ is based on the selectivity coefficient $\left(W_{i}\right)$ and ranges from -1 to +1 : a 0 value indicates random feeding, +1 indicates maximum preference and -1 indicates maximum avoidance (Lechowicz 1982).

\section{RESULTS}

\section{Feeding}

We encountered slow lorises 216 times during the study period in HGWLS. Animals were fully nocturnal and were observed between 18:00 and 04:30 h. We recorded 629 feeding bouts. Consumption of different plant parts was clearly dominated by plant 
exudates (mean \pm SD: $80.93 \pm 5.24 \%$ ), followed by plant bark $(7.28 \pm 2.49 \%)$, fruits $(4.45 \pm 0.74 \%)$, flower nectar $(3.19 \pm 0.89 \%)$, invertebrates $(2.32 \pm$ $1.98 \%)$ and immature leaves $(1.83 \pm 1.6 \%)$.

Seasonal variation occurred in the percentage of time spent feeding on different food types. During winter, exudate consumption increased $(85.27 \%$ in winter compared with $76.47 \%$ in summer). Plant bark consumption increased in summer $(9.21 \%$ in summer and $5.55 \%$ in winter). Similar trends of increasing feeding percentage are also found for immature leaves (summer $3.12 \%$, winter $0.54 \%$ ) and invertebrates (summer $3.28 \%$, winter $1.35 \%$; Fig. 2).

Bengal slow lorises consumed exudates $(\mathrm{n}=509)$ for 2 to $20 \mathrm{~min}$, at an average time of $4.26 \pm 2.74 \mathrm{~min}$. They actively gouged gum with the anterior teeth, in many different postures, including head up or head down on the trunk, standing over a branch, or bridging 2 substrates. In most cases, trees already bore wounds (due to larval infestation, prior injury, or fire), although lorises also gouged into the wood to induce gum flow.

\section{Plant taxa used as sources of food}

Bengal slow lorises used 56 plant species (44 trees and 12 lianas/climbers) belonging to 23 families as a source of food (Table 1). Only 26 plant species were recorded for more than $1 \%$ of feeding effort, accounting for $80.15 \%$ of the total feeding time. Nontree species (lianas/climbers) made up $18.58 \%$ of feeding records. Moraceae was the most important

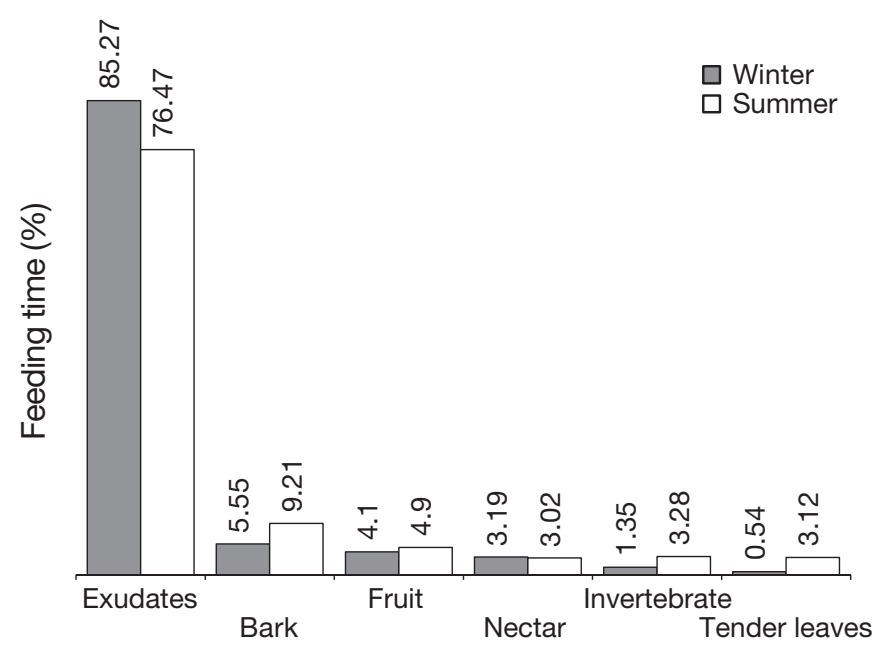

Fig. 2. Nycticebus bengalensis. Percent of total feeding time (values above bars) spent on different food categories in winter and summer seasons, showing that in both seasons, exudates were the predominant food type consumed family, with 10 species used as food sources, mainly Ficus spp.

The top 15 food plants collectively made up 59.9\% of the overall feeding time. When lianas are included in this analysis, the top 15 food items accounted for $68.29 \%$ of the total feeding time (Table 2).

To examine whether species were chosen based on their relative abundance in the habitat, we calculated $E_{i}^{*}$ only for plant species that were used by Bengal slow lorises $1 \%$ or more of the time for exudate feeding (13 plant species in winter and 11 plant species in summer; Table 3).

Although a higher percentage of time was spent on exudate feeding of the plant Terminalia chebula in winter $(21.61 \%$, feeding preference: +0.297$), E_{i}^{*}$ indicated that it was not one of the most preferred species, whereas $T$. arjuna $(14.57 \%$, feeding preference: $+0.398)$ and Vatica lanceaefolia $(10.51 \%$, feeding preference: +0.297 ) were the most preferred (Fig. 3). In summer, the preference of exudates changed to $T$. arjuna and Mesua ferrea, which accounted for 14.44 (feeding preference: +0.405 ) and $22.32 \%$ (feeding preference: +0.393 ) of the total exudate feeding time, respectively. Feeding on $T$. chebula remained high in summer (Fig. 4).

\section{DISCUSSION}

We found that the major part of the diet of Bengal slow lorises is comprised of plant exudates, accounting for $80.93 \%$ of total feeding time. Studies on Bengal slow loris diet in Thailand and Tripura, India, have also concluded that this species predominantly consumes exudates (Swapna et al. 2009, Pliosungnoen et al. 2010), meaning that this food type is important, irrespective of habitat type. Bengal slow lorises consumed a variety of food types including both plant material (exudates, nectar, bark, tender leaves and fruit) and animal prey (invertebrates). We should note that observations of animal prey are the most difficult to see and are probably under-recorded here.

Consumption of plant exudates has now been observed year-round for 4 slow loris species (Nycticebus coucang, Wiens et al. 2006; N. pygmaeus, N. javanicus, Starr \& Nekaris 2013; N. bengalensis, present study). Exudates are the main components of diet of the greater slow loris $N$. coucang $(43 \%)$, pygmy slow loris $N$. pygmaeus (63\%: reintroduced; $51 \%$ : wild) and Javan slow loris N. javanicus (54\%) (Streicher 2004, Wiens et al. 2006, Starr \& Nekaris 2013). We concur with Swapna et al. (2009) and Starr \& Nekaris (2013) that exudates are a preferred rather 
Table 1. Nycticebus bengalensis. Food plants used by Bengal slow lorises in the Hollongapar Gibbon Wildlife Sanctuary, India. Moracaeae was the dominant family from which foods were consumed. EX: exudates; BR: bark; FR: fruits; NC: nectar; TL: tender (i.e. immature) leaves

\begin{tabular}{|c|c|c|c|}
\hline Family & Species & $\begin{array}{l}\text { Plant parts } \\
\text { consumed }\end{array}$ & Plant type \\
\hline \multirow[t]{6}{*}{ Anacardiaceae } & Mangifera sylvatica & $\mathrm{EX}, \mathrm{NC}$ & Tree \\
\hline & Pegia nitida & $\mathrm{EX}, \mathrm{BR}$ & Climber \\
\hline & Spondius mangifera & EX, FR & Tree \\
\hline & Rhus semialata & $\mathrm{BR}, \mathrm{FR}, \mathrm{TL}$ & Tree \\
\hline & Spondia spinnata & FR, TL & Tree \\
\hline & Lannea grandis & EX, FR & Tree \\
\hline Araceae & Pothos scandens & EX & Liana \\
\hline Asteraceae & Vernonia scandens & $\mathrm{NC}$ & Liana \\
\hline Aquifoliaceae & Ilex godjam & $\mathrm{BR}$ & Tree \\
\hline Burseraceae & Canarium bengalensis & $\mathrm{EX}, \mathrm{BR}$ & Tree \\
\hline \multirow[t]{4}{*}{ Combretaceae } & Terminalia chebula & $\mathrm{EX}, \mathrm{BR}, \mathrm{FR}, \mathrm{NC}$ & Tree \\
\hline & Terminalia arjuna & $\mathrm{EX}, \mathrm{BR}$ & Tree \\
\hline & Terminalia myriocarpa & $\mathrm{EX}, \mathrm{BR}, \mathrm{NC}$ & Tree \\
\hline & Combretum acuminatum & TL & Liana \\
\hline \multirow[t]{4}{*}{ Clusiaceae } & Mesua ferrea & EX, FR & Tree \\
\hline & Garcinia pedunculata & FR, TL & Tree \\
\hline & Garcinia cowa & EX & Tree \\
\hline & Garcinia kydia & EX & Tree \\
\hline Dilleniaceae & Dillenia indica & $\mathrm{EX}, \mathrm{NC}$ & Tree \\
\hline Dipterocarpaceae & Vatica lanceaefolia & $\mathrm{EX}, \mathrm{NC}$ & Tree \\
\hline Dioscoreaceae & Dioscorea bulbifera & FR, TL & Liana/Vine \\
\hline \multirow[t]{3}{*}{ Euphorbieacea } & Endospermum chinensis & TL & Tree \\
\hline & Antidesma diandrum & $\mathrm{EX}, \mathrm{TL}$ & Tree \\
\hline & Bridelia stipularis & EX & Climber \\
\hline \multirow[t]{5}{*}{ Fabaceae } & Dalbergia assamica & EX, TL & Tree \\
\hline & Dalbergia volubilis & EX & Liana \\
\hline & Dalbergia stipulacea & EX & Liana \\
\hline & Dalbergia rimosa & $\mathrm{EX}$ & Liana \\
\hline & Spatholobus roxburghii & EX & Liana \\
\hline \multirow[t]{2}{*}{ Fagaceae } & Castonopsis indica & EX, BR, FR & Tree \\
\hline & Castonopsis tribuloides & $\mathrm{EX}$ & Tree \\
\hline Hamamelidaceae & Altingia excelsa & EX & Tree \\
\hline Lecythidaceae & Careya arborea & EX & Tree \\
\hline Leguminosae & Entada phaseoloides & EX & Liana/Vine \\
\hline \multirow[t]{2}{*}{ Lythraceae } & Lagerstroemia reginae & $\mathrm{EX}, \mathrm{BR}, \mathrm{FR}, \mathrm{NC}$ & Tree \\
\hline & Duabanga grandiflora & EX & Tree \\
\hline \multirow[t]{2}{*}{ Magnoliaceae } & Magnolia hodgsonii & $\mathrm{EX}, \mathrm{NC}$ & Tree \\
\hline & Manglietia hookeri & EX & Tree \\
\hline \multirow[t]{4}{*}{ Meliaceae } & Melia azedarach & $\mathrm{EX}, \mathrm{BR}$ & Tree \\
\hline & Dysoxylum binectariferum & EX & Tree \\
\hline & Dysoxylum grande & EX & Tree \\
\hline & Dysoxylum proccerum & $\mathrm{TL}$ & Tree \\
\hline \multirow[t]{10}{*}{ Moraceae } & Ficus hispida & $\mathrm{EX}, \mathrm{BR}$ & Tree \\
\hline & Artocarpus chama & EX, NC & Tree \\
\hline & Artocarpus lakoocha & $\mathrm{EX}, \mathrm{FR}, \mathrm{BR}$ & Tree \\
\hline & Ficus rumphii & EX, BR & Tree \\
\hline & Ficus nerifolia & $\mathrm{EX}, \mathrm{BR}$ & Tree \\
\hline & Ficus bengalensis & $\mathrm{EX}, \mathrm{BR}$ & Tree \\
\hline & Ficus benjamina & $\mathrm{EX}, \mathrm{BR}$ & Tree \\
\hline & Ficus fistulosa & EX, FR & Tree \\
\hline & Ficus heterophylla & BR & Liana \\
\hline & Morus indica & FR & Tree \\
\hline Poaeceae & Pseudostachyum polymorphun & $\mathrm{TL}$ & Tree \\
\hline \multirow[t]{2}{*}{ Rubiaceae } & Uncaria laevigata & TL & Liana \\
\hline & Anthocephalus chinensis & EX, FR & Tree \\
\hline Sterculiaceae & Pterospermum acerifolium & EX, BR, TL & Tree \\
\hline
\end{tabular}

than a fallback food. As reiterated below, the consistent inclusion of high proportions of gums, including gums that occur at relatively low abundance, reinforces this assertion.

We analysed the proportion of each dietary item and established that Bengal slow lorises ate certain species and preferred them over others, according to their relative abundance in the habitat. The fact that $80.93 \%$ of the Bengal slow loris diet comprises plant exudates reinforces the view that these are preferred foods. Terminalia arjuna was the most preferred, used for exudate feeding both in winter and summer seasons. Lagerstroemia reginae was the most abundant plant species in our study plots, but was not one of the preferred species in any season. Instead, the preferred species in winter and summer were T. arjuna, Vatica lanceaefolia, $T$. chebula, Mesua ferrea and Spondias pinnata. The preferred plant species were comparatively less abundant than the non-preferred species. Although $E_{i}^{*}$ provides the single best electivity index (Lechowicz 1982), more information is required on the nutritional content of and seasonal changes in the composition of exudates (Power 2010). Exudates are available yearround and are known to vary seasonally in chemical composition and moisture content (Wiens 2002, Nash \& Burrows 2010). Future qualitative analysis may reveal that this is a major factor influencing the choice of plant species by these primates.

Any nutritional analysis of exudates should keep in mind the finding that 5 of the most preferred plant species of Bengal slow lorises are known to have high medicinal value for humans, who use them as traditional cures. Various components of these plants (Terminalia arjuna, Vatica lanceaefolia, T. chebula, 
Table 2. Nycticebus bengalensis. Plant items from trees and lianas frequently consumed by Bengal slow lorises and percent of total feeding time spent feeding on those species. EX: exudates; BR: bark; FR: fruits; NC: nectar; TL: tender (i.e. immature) leaves

\begin{tabular}{|lcc|}
\hline Plant species & $\begin{array}{c}\text { Plant parts } \\
\text { consumed }\end{array}$ & $\begin{array}{c}\text { \% of } \\
\text { feeding time }\end{array}$ \\
\hline Terminalia chebula & EX, FR, NC, BR & 17.76 \\
Mesua ferrea & EX & 10.62 \\
Terminalia arjuna & EX, BR & 5.85 \\
Vatica lanceaefolia & EX, NC, BR & 4.54 \\
Entada phaseoloides & EX & 4.34 \\
Pothos Scandens & EX & 4.21 \\
Dioscorea bulbifera & FR, TL & 3.56 \\
Terminalia myriocarpa & EX & 2.81 \\
Spondias mangifera & EX, FR & 2.75 \\
Castonopsis indica & EX, FR & 2.73 \\
Lagerstroemia reginae & EX, BR & 2.32 \\
Ficus hispida & EX & 2.04 \\
Artocarpus chama & EX & 1.75 \\
Dillenia indica & EX, NC & 1.58 \\
Morus indica & FR & 1.43 \\
& & $\mathbf{6 8 . 2 9}$ \\
\hline
\end{tabular}

Mesua ferrea and Spondias pinnata) are widely used by Indian Ayurvedic medicine systems as well as by the traditional medicine practitioners in the region. Other loris species (Nycticebus pygmaeus, N. javanicus, Loris tardigradus, L. lydekkerianus) also consume medicinal plants, and this could be of interest to understanding their ecology and conservation (Table 4).

A number of the medicinal plants consumed by lorises have pharmacological importance and have antiparasitic, antifungal, antibacterial, antiviral cardiotonic and stimulatory properties, as well as uses in

Table 3. Nycticebus bengalensis. Proportion of time spent on exudativory of different plant species in relation to plant availability

\begin{tabular}{|lccc|}
\hline \multirow{2}{*}{ Plant species } & \multicolumn{2}{c}{ Exudate feeding (\%) } & \multirow{2}{*}{ Plant abundance (\%) } \\
& Winter & Summer & \\
\hline Terminalia chebula & 21.61 & 16.44 & 2.01 \\
Dillenia indica & 3.38 & 1.33 & 0.78 \\
Mesua ferrea & 13.81 & 22.32 & 1.78 \\
Terminalia arjuna & 14.57 & 14.44 & 1.12 \\
Ficus hispida & 8.06 & 5.38 & 1.43 \\
Vatica lanceaefolia & 10.51 & 8.39 & 1.01 \\
Melia azedarach & 1.23 & - & 0.25 \\
Spondias pinnata & 6.78 & 5.68 & 0.87 \\
Magnolia hodgsonii & 2.32 & - & 4.39 \\
Castonopsis indica & 3.29 & 7.95 & 5.78 \\
Terminalia myriocarpa & 7.85 & 9.07 & 2.98 \\
Lagerstroemia reginae & 3.22 & 6.23 & 6.48 \\
Pterospermum acerifolium & 3.37 & - & 0.79 \\
Artocarpus chama & - & 2.77 & 4.76 \\
\hline
\end{tabular}

respiratory disease and wound healing cures in traditional medicines. Inclusion of medicinal plants in their diet might have implications for the physiology of slow lorises. Forbey et al. (2009) suggested that high exploitation of secondary metabolites from plant materials may provide various natural selection advantages for animals and that the ability to utilise these chemicals is more common than previously thought. Wiens et al. (2006) already suggested that the extremely low basal metabolism of slow lorises is an adaptation to digest toxic secondary compounds found in their exudate-based diet. Sequestration of chemicals from secondary metabolites provides an array of known benefits to many taxa, including primates (Huffman 2003). One major benefit is reduction of ectoparasites, whereby sequestered secondary metabolites may be rubbed on fur, applied with saliva or exuded through the skin (Lozano 1998). Indeed, a review of all loris taxa studied to date revealed the extremely low degree of ectoparasites (Nekaris et al. 2013), and some of the medicinal plants eaten by lorises are known to have anti-parasitic properties (Mulla \& Su 1999, Katz et al. 2008).

Slow lorises are the only known venomous primates (Alterman 1995). Consumption of foods containing various secondary metabolites and subsequent sequestration of these compounds may not only contribute to the biochemistry of slow loris venom, but may also aid in healing of wounds inflicted by a slow loris (Nekaris et al. 2013). Death from necrotic bites delivered by conspecifics was found to be one of the major causes of death to 5 different species of slow loris, both in zoos and rescue centres (Streicher 2004). The wounds inflicted on slow lorises by conspecifics are severe, resulting in the loss of ears, hands, and even whole limbs. These bite wounds rarely heal in captivity, but mend with remarkable success in the wild (Streicher 2004, Nekaris et al. 2013). Nekaris et al. (2013) hypothesized that wild lorises may consume foods that their captive counterparts lack, leading to this healing process. A greater understanding of the role of such plants in loris diet and of the way these plants may be used for health maintenance is a promising new avenue not only for expanding our understanding of loris health in captivity, but also may yield the potential for developing novel applications of ethnopharmacological knowledge (Huffman et al. 1998). 


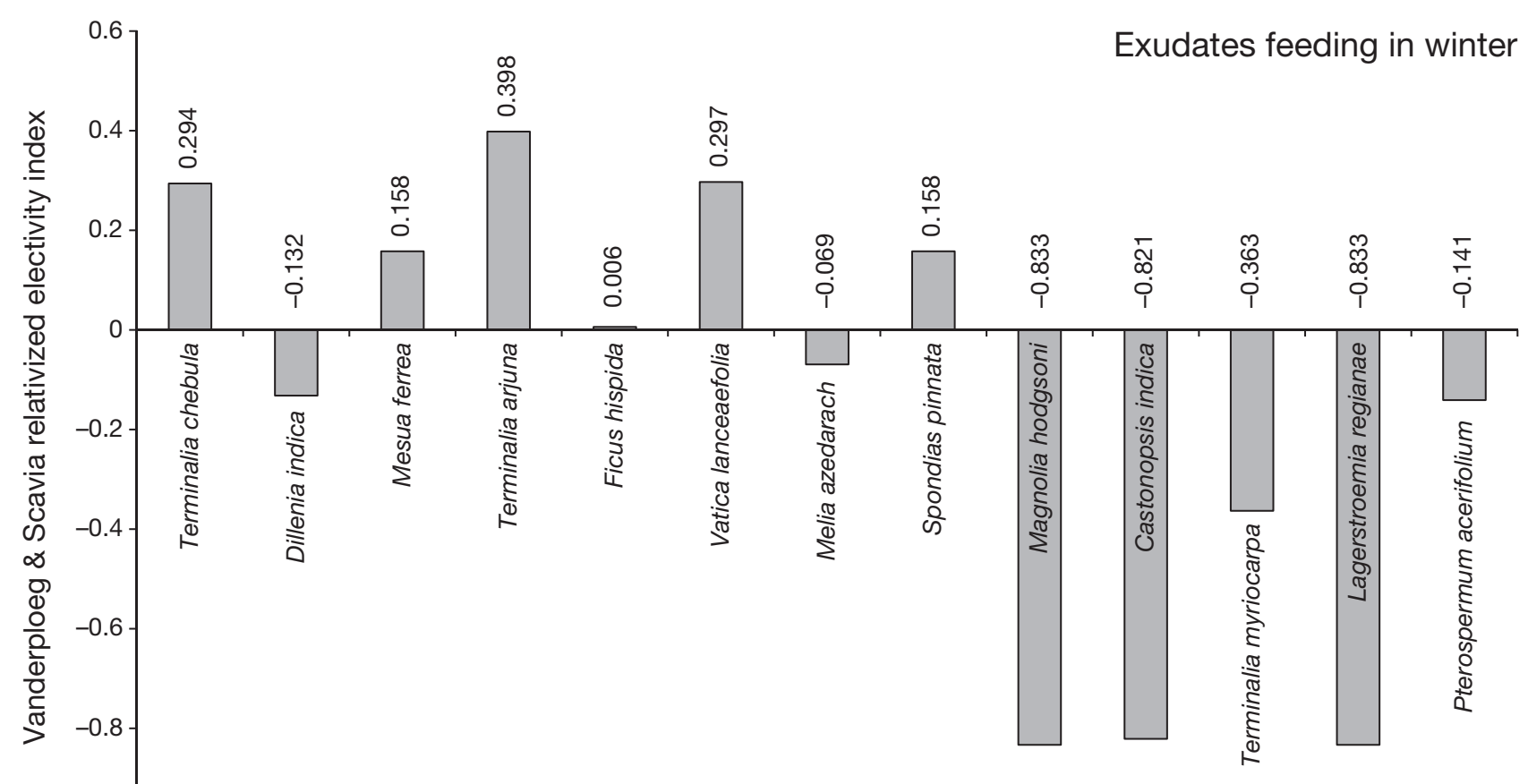

Fig. 3. Nycticebus bengalensis. Electivity index $\left(E_{i}^{*}\right)$ for exudates consumed during the winter (exact values given above bars)

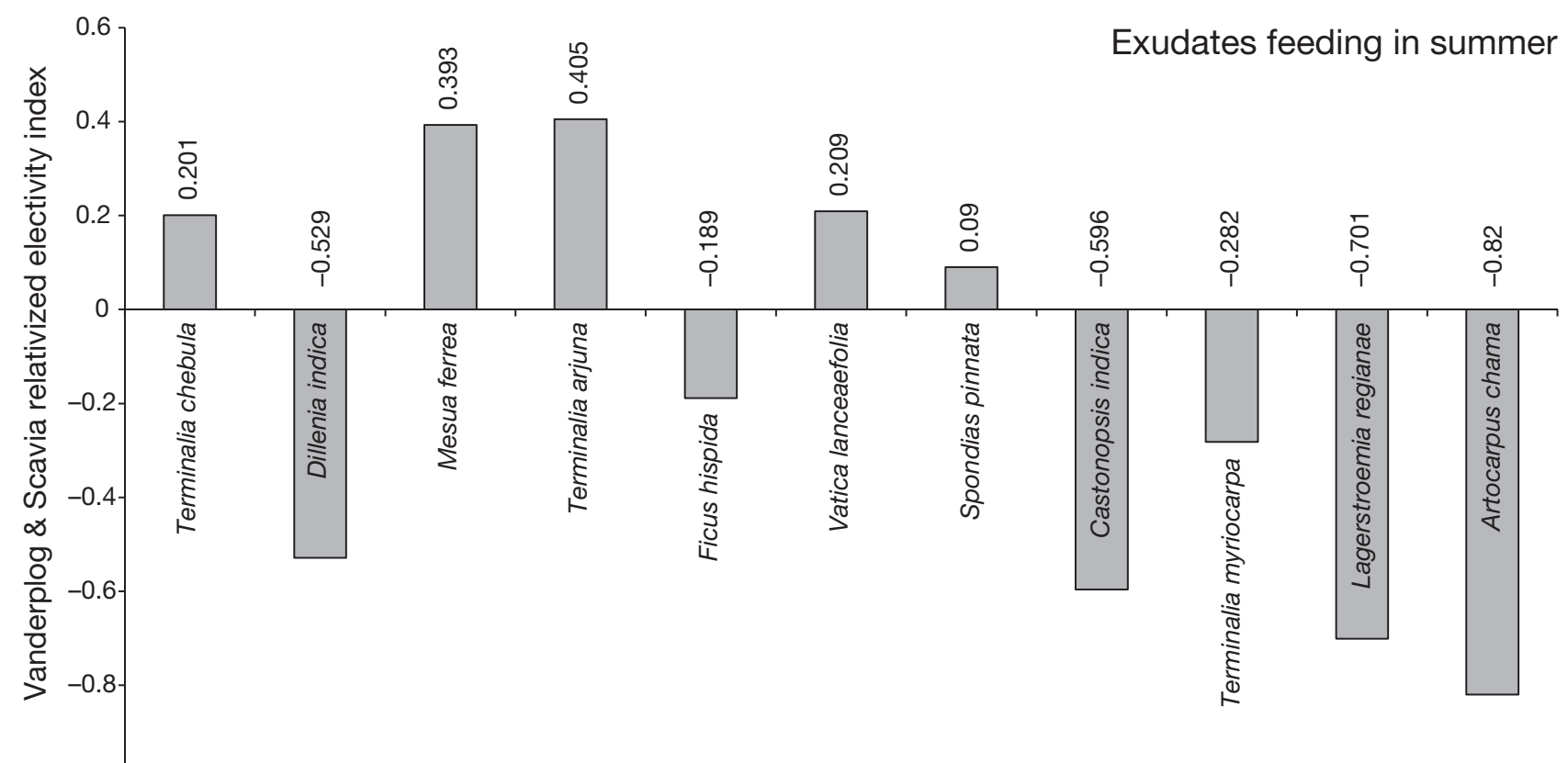

Fig. 4. Nycticebus bengalensis. Electivity index $\left(E_{i}^{*}\right)$ for exudates consumed during the winter (exact values given above bars)

Use of ethno-pharmacological plants may also have implications for the conservation of slow lorises. Slow lorises are among the most widely used species for traditional medicines in Indochina (Starr et al. 2010). Some of the pharmacological uses of plants consumed by slow lorises in our study mirror those reported by traditional medicine practitioners, including curing indigestion, various stomach ailments and heart diseases. Whether or not there is any scientific validity behind 'slow loris medicine', the fact that both Indochinese species are now known to consume plants with medicinal value is of interest (Table 4). It 
Table 4. Nycticebus and Loris spp. Comparative analysis of medicinal uses of preferred plants of slow and slender lorises

\begin{tabular}{|c|c|c|}
\hline Loris species & Plant species & Medicinal uses \\
\hline $\begin{array}{l}\text { N. bengalensis } \\
\text { (present study) }\end{array}$ & Terminalia arjuna & $\begin{array}{l}\text { Prevention and treatment of heart diseases including angina, } \\
\text { heart failure and hypercholesterolaemia (Acharyya \& Sharma 2004) }\end{array}$ \\
\hline $\begin{array}{l}\text { N. bengalensis } \\
\text { (present study) }\end{array}$ & Terminalia chebula & $\begin{array}{l}\text { Digestive aid and treatment of bleeding gums. Extracts used for treat- } \\
\text { ment of hepatitis. Fruits used as appetite stimulants and in treatment } \\
\text { of smallpox. Also used for liver disorders (Sajem \& Gosai 2006) }\end{array}$ \\
\hline $\begin{array}{l}\text { N. bengalensis } \\
\text { (present study) }\end{array}$ & Spondias pinnata & $\begin{array}{l}\text { Antifungal properties. Used for treatment of diarrhoea, otalgia, } \\
\text { and dyspepsia, among other uses (Saikia et al.2010) }\end{array}$ \\
\hline $\begin{array}{l}\text { N. bengalensis } \\
\text { (present study) }\end{array}$ & Mesua ferrea & $\begin{array}{l}\text { Fresh flowers used as cure for excessive perspiration, excessive thirst, } \\
\text { indigestion, and cough. Dried blossoms used as cure for mucus } \\
\text { dysentery and bleeding haemorrhoids (Acharyya \& Sharma 2004) }\end{array}$ \\
\hline $\begin{array}{l}\text { N. bengalensis } \\
\text { (present study) }\end{array}$ & Vatica lanceaefolia & Bark used in dysentery (Purkayastha et al. 2007) \\
\hline $\begin{array}{l}\text { N. pygmaeus } \\
\text { (Starr \& Nekaris 2013) }\end{array}$ & Salacia chinensis & $\begin{array}{l}\text { Used in Ayurvedic medicine as an antioxidant, anti-caries, anti-ulcer, } \\
\text { anti-diabetic, anti-obesity hypoglycaemia, and skin lightening agent } \\
\text { (Deokate \& Khadabadi 2012) }\end{array}$ \\
\hline $\begin{array}{l}\text { N. javanicus } \\
\text { (E. J. Rode et al. } \\
\text { unpubl.) }\end{array}$ & Melaleuca leucadendra & $\begin{array}{l}\text { Stimulant, antiseptic, aromatic functions; increases cardiac action; } \\
\text { antimalarial action; aids curing microbial diseases of lungs and } \\
\text { bronchitis; remedy for hookworm; used in veterinary practice for skin } \\
\text { infections and septicaemia (Hammer et al. 1999) }\end{array}$ \\
\hline $\begin{array}{l}\text { N. javanicus } \\
\text { (E. J. Rode et al. } \\
\text { unpubl.) }\end{array}$ & Acacia decurrens & $\begin{array}{l}\text { In Ayurvedic medicine, used to expel worms, staunch bleeding, } \\
\text { heal wounds, cure diarrhoea and suppress the coughing up of blood; } \\
\text { antibacterial and anti-inflammatory; cures microbial infections } \\
\text { (Nussinovitch 2010) }\end{array}$ \\
\hline $\begin{array}{l}\text { L. tardigradus } \\
\text { (Nekaris et al. 2005) }\end{array}$ & Coscinium fenestratum & $\begin{array}{l}\text { Used in Ayurvedic medicine for diabetes, poultice, cuts, sores, ulcers, } \\
\text { fever, jaundice, snake bites (Rai et al. 2013) }\end{array}$ \\
\hline $\begin{array}{l}\text { L. tardigradus } \\
\text { (Nekaris et al. 2005) }\end{array}$ & Lantana camara & Anti-bacterial and anti-fungal properties (Deena \& Thoppil 2000) \\
\hline $\begin{array}{l}\text { L. lydekkerianus } \\
\text { (Nekaris \& } \\
\text { Rasmussen 2003) }\end{array}$ & Azadirachta indica & $\begin{array}{l}\text { Used in Ayurvedic medicine for fatigue, cough, fever, loss of appetite, } \\
\text { worm infestation; heals vomiting, skin diseases, excessive thirst and } \\
\text { diabetes. Beneficial for eye disorders and insect bites. Used against heat } \\
\text { rash, boils, wounds, jaundice, leprosy, skin disorders, stomach ulcers } \\
\text { and chicken pox; has veterinary applications (Koul et al. 1990) }\end{array}$ \\
\hline
\end{tabular}

is possible that in the distant past, lorises became associated with the medicinal plants they were eating, leading local people to believe that lorises may possess the same medicinal properties. Finding a positive relationship between lorises and medicinal plants, such as their role as potential pollinators, may aid in their conservation.

Acknowledgements. We thank the Department of Environment \& Forest, Government of Assam, India, for providing the necessary permission to carry out the study. We thank all concerned officials at the study sites for allowing us to study at night and providing all logistical support. We also thank J. Biswas, J. Das, P. Chandra Ray and A. Sangma of the Primate Research Centre NE India for help during this study. Our field assistants D. Borah and S. Gonju are also acknowledged. This study was supported by grants from Rufford Small Grants Foundation (grant no. 7836-2), Mohamed Bin Zayed Species Conservation Fund (grant no. 0925286), Primate Action Fund of Conservation International to N.D. and Leverhulme Trust (grant no. RPG-084) to K.A.I.N.

\section{LITERATURE CITED}

Acharyya BK, Sharma HK (2004) Folklore medicinal plants of Mahmora area, Sivasagar District, Assam. Indian J Trad Knowledge 3:365-372

Alterman L (1995) Toxins and toothcombs: potential allospecific chemical defenses in Nycticebus and Perodicticus. In: Alterman L, Doyle GA, Izard MK (eds) Creatures of the dark - the nocturnal prosimians. Springer, New York, NY, p 413-424

Altmann J (1974) Observational study of behaviour: sampling methods. Behaviour 49:227-267

Champion HG, Seth SK (1968) A revised survey of forests types of India. Manager of Publication, New Delhi

Deena MJ, Thoppil JE (2000) Antimicrobial activity of the essential oil of Lantana camara. Fitoterapia 71:453-455

Deokate UA, Khadabadi SS (2012) Phytopharmacological aspects of Salacia chinensis. J Pharmacogn Phytother 4: $1-5$

Eisenberg JF, Muckenhim NA, Rudran R (1972) The relation between ecology and social structure in primates. Science 176:863-874

Forbey JS, Harvey AL, Huffman MA, Provenza FD, Sullivan $\mathrm{R}$, Tasdemir D (2009) Exploitation of secondary metabo- 
lites by animals: a response to homeostatic challenges. Integr Comp Biol 49:314-328

Ganzhorn JU (2002) Distribution of a folivorous lemur in relation to seasonally varying food resources: integrating quantitative and qualitative aspects of food characteristics. Oecologia 131:427-435

> Garber PA (1987) Foraging strategies among living primates. Annu Rev Anthropol 16:339-364

- Hammer KA, Carson CF, Riley TV (1999) Antimicrobial activity of essential oils and other plant extracts. J Appl Microbiol 86:985-990

Heymann EW, Smith AC (1999) When to feed on gums: temporal patterns of gummivory in wild tamarins, Saguinus mystax and Saguinus fuscicollis (Callitrichinae). Zoo Biol 18:459-471

Hladik A (1978) Phenology of leaf production in rain forest of Gabon: distribution and composition of food for folivores. In: Montgomery GG (eds) The ecology of arboreal folivores. Smithsonian Institution Press, Washington, DC, p 51-71

Huffman MA (2003) Animal self-medication and ethno-medicine: exploration and exploitation of the medicinal properties of plants. Proc Nutr Soc 62:371-381

Huffman MA, Ohigashi H, Kawanka M, Page JE and others (1998) African great ape self-medication, a new paradigm for treating parasite disease with natural medicines? In: Ageta H, Aimi N, Ebizuka Y, Fujija T, Honda G (eds) Towards natural medicine research in the 21st century. Elsevier Science, Amsterdam, p 113-122

Katz TM, Miller JH, Hebert AA (2008) Insect repellents: historical perspectives and new developments. J Am Acad Dermatol 58:865-871

Koul O, Isman MB, Ketkar CM (1990) Properties and uses of neem Azadirachta indica. Can J Bot 68:1-11

> Lechowicz JM (1982) The sampling characteristics of electivity indices. Oecologia 52:22-30

Lehman SM, Mayor M, Wright PC (2005) Ecogeographic size variations in sifakas: a test of the resource seasonality and resource quality hypotheses. Am J Phys Anthropol 126: 318-328

Lozano GA (1998) Parasitic stress and self-medication in wild animals. Adv Stud Behav 27:291-317

Marshall AJ, Wrangham RW (2007) Evolutionary consequences of fallback foods. Int J Primatol 28:1219-1235

Mulla MS, Su T (1999) Activity and biological effects of neem products against arthropods of medical and veterinary importance. J Am Mosq Control Assoc 15:133-152

Nash LT, Burrows A (2010) Advances and remaining sticky issues in the understanding of exudativory in primates. In: Burrows AM, Nash LT (eds) The evolution of exudativory in primates. Springer, New York, NY, p 1-24

Nekaris KAI (2001) Activity budget and positional behavior of the Mysore slender loris (Loris tardigradus lydekkerianus): implications for slow climbing locomotion. Folia Primatol 72:228-241

Nekaris KAI, Rasmussen DT (2003) Diet of the slender loris. Int J Primatol 24:33-46

> Nekaris KAI, Liyanage WKDD, Gamage S (2005) Relationship between forest structure and floristic composition and population density of the south western Ceylon slender loris (Loris tardigradus tardigradus) in Masmullah Forest, Sri Lanka. Mammalia 69:1-10

Nekaris KAI, Starr CR, Collins RL, Wilson A (2010) Comparative ecology of exudate feeding by Asian slow lorises ( $\mathrm{NyC}$ ticebus). In: Burrows AM, Nash LT (eds) The evolution of exudativory in primates. Springer, New York, NY, p 155-168

> Nekaris KAI, Campbell N, Coggins TG, Rode EJ, Nijman V

Editorial responsibility: Anna Nekaris,

Oxford, UK
(2013) Tickled to death: analysing public perceptions of 'cute' videos of threatened species (slow lorises - Nycticebus spp.) on Web 2.0 sites. PLoS ONE 8:e69215

Nussinovitch A (2010) Plant gum exudates of the world: sources, distribution, properties, and applications. CRC Press, Boca Raton, FL

Pliosungnoen M, Gale G, Savini T (2010) Density and microhabitat use of Bengal slow loris in primary forest and nonnative plantation forest. Am J Primatol 72:1108-1117

Poulsen JR, Clark CJ, Smith TB (2001) Seasonal variation in the feeding ecology of the grey-cheeked mangabey (Lophocebus albigena) in Cameroon. Am J Primatol 54: 91-105

Power ML (2010) Nutritional and digestive challenges to being a gum-feeding primate. In Burrows AM, Nash LT (eds) The evolution of exudativory in primates. Springer, New York, NY, p 25-44

> Powzyk JA, Mowry CB (2003) Dietary and feeding differences between sympatric Propithecus diadema diadema and Indri indri. Int J Primatol 24:1143-1162

Purkayastha J, Dutta M, Nath SC (2007) Ethnomedicinal plants from Dibru-Saikhowa Biosphere Reserve, Assam. Indian J Trad Knowledge 6:477-480

Rai RV, Rajesh PS, Kim HM (2013) Medicinal use of Coscinium fenestratum (Gaertn.) Colebr.: an short review. Orient Pharm Exp Med 13:1-9

- Ravosa MJ (1998) Cranial allometry and geographic variation in slow lorises (Nycticebus). Am J Primatol 45:225-243

Rogers LD, Nekaris KAI (2011) Behaviour and habitat use of the Bengal slow loris Nycticebus bengalensis in the dry dipterocarp forests of Phnom Samkos Wildlife Sanctuary, Cambodia. Cambod J Nat Hist 2:92-103

Saikia B, Borthakur SK, Saikia N (2010) Medico-ethnobotany of Bodo tribals in Gohpur of Sonitpur district, Assam. Indian J Trad Knowledge 9:52-54

Sajem AL, Gosai K (2006) Traditional use of medicinal plants by the Jaintia tribes in North Cachar Hills district of Assam, northeast India. J Ethnobiol Ethnomed 2:33

Smith A (2010) Exudativory in primates: interspecific patterns. In: Burrows AM, Nash LT (eds) The evolution of exudativory in primates. Springer, New York, NY, p 45-88

Starr CR, Nekaris KAI (2013) Obligate exudativory characterizes the diet of the pygmy slow loris Nycticebus pygmaeus. Am J Primatol 75:1054-1061

Starr C, Nekaris KAI, Streicher U, Leung L (2010) Traditional use of slow lorises Nycticebus bengalensis and N. pygmaeus in Cambodia: an impediment to their conservation. Endang Species Res 12:17-23

Streicher U (2004) Confiscated primates - health aspects and long-term placement options. In: Nadler T, Streicher U, Long HT (eds) Conservation of primates in Vietnam. Frankfurt Zoological Society, Frankfurt, p 154-160

Struhsaker TT (1975) The red colobus monkey. University of Chicago Press, Chicago, IL

Swapna N, Radhakrishna S, Gupta AK, Kumar A (2009) Exudativory in the Bengal slow loris (Nycticebus bengalensis) in Trishna Wildlife Sanctuary, Tripura, Northeast India. Am J Primatol 72:113-121

Wiens F (2002) Behavior and ecology of wild slow lorises (Nycticebus coucang): social organisation, infant care system and diet. PhD thesis, Bayreuth University

> Wiens F, Zitzmann A, Hussein NA (2006) Fast food for slow lorises: Is low metabolism related to secondary compounds in high-energy plant diet? J Mammal 87:790-798

Williamson EA (1993) Methods used in the evaluation of lowland gorilla habitat in the Lope Reserve, Gabon. Tropics 2: 199-208

Submitted: July 2, 2013; Accepted: October 22, 2013

Proofs received from author(s): February 4, 2014 